\title{
A proteomic analysis of the regulon of the NarP two-component regulatory system response regulator in the bovine pathogen Mannheimia haemolytica $\mathrm{A} 1$
}

Ichiro Inamoto and Reggie Lo YC Lo*

\begin{abstract}
Background: The response of the NarQP two-component signal transduction system regulon in response to the presence of nitrate for the bovine pathogen Mannheimia haemolytica A1 was investigated by proteomic analysis. Total proteins from a narP mutant and the parent $\mathrm{SH} 1217$ grown with or without $\mathrm{NaNO}_{3}$ supplement were examined by ISO-DALT 2D electrophoresis and liquid chromatography-mass spectrometry.

Results: Seventeen proteins were differentially expressed in the parent strain SH1217 in response to the addition of $\mathrm{NaNO}_{3}$ to the growth media. These responses were absent in the narP mutant, indicating that the altered production of these proteins is mediated by NarP ${ }_{M h}$. Interestingly, NarP $\mathrm{Mh}_{\text {h }}$ mediated the increased production of some proteins which are not generally associated with nitrate respiration, such as the iron transporters FbpA and YfeA. The increased production of proteins such as superoxide dismutase, SodA, and GAPDH were also observed. The increased production of these iron-regulated proteins by NarP $\mathrm{Mh}_{\mathrm{h}}$ is thought to enhance the swift establishment of the nitrate respiration mechanism of $M$. haemolytica during pathogenesis.
\end{abstract}

Conclusion: The data suggested $\mathrm{NarP}_{M h}$ acts as an important regulator which regulates the expression of a small set of proteins in response to nitrate availability. This may contribute to the prevalence of $M$. haemolytica A1 in its host during pathogenesis of BPP, through enhancing the effectiveness of nitrate respiration either directly or indirectly.

Keywords: narP mutant, 2D electrophoresis, LC-MS

\section{Background}

Mannheimia haemolytica A1 is a Gram-negative, nonmotile coccobacillus normally found in the upper respiratory tract of healthy calves. This bacterium is an opportunistic pathogen which causes bovine pneumonic pasteurellosis (BPP), an acute pneumonia that often leads to death in the animals $[1,2]$. BPP usually occurs after transportation of calves from the farm to feedlot and is also known as 'shipping fever'. It has been estimated that over $\$ 1$ billion is lost annually in North America due to this disease [3,4].

\footnotetext{
*Correspondence: rlo@uoguelph.ca

* Correspondence: rlo@uoguelph.ca
Department of Molecular and Cellular Biology, University of Guelph, Guelph, ON, N1G 2W1, Canada
}

Environmental stresses such as transportation, crowding and viral infection also play a major role in the pathogenesis of BPP [5]. Exposure to these stress factors compromises the immune system of the animal allowing $M$. haemolytica A1 to multiply and infect the lung through aerosol and gravitational movement. Many virulence factors such as the leukotoxin, $O$-sialoglycoprotease and adhesins are expressed by the bacterium during infection which contribute to the disease $[6,7]$. Since $M$. haemolytica A1 is an opportunistic pathogen, expression of these virulence factors are likely to respond to specific environmental signal(s).

Two-component signal transduction systems (TCSs) are environmental response mechanisms commonly found in bacterial species and in some eukaryotes [8]. 
Previously, we have identified five putative pairs of TCSs in the M. haemolytica A1 genome; ArcBA, CpxRA, NarQP, PhoRB and TtrSR. Out of these, the nitrate sensory system, NarQP ${ }_{M h}$, was further investigated by the generation of a narP knock-out mutant [9]. We showed that the production of some proteins was differentially regulated in the parental strain in response to the addition of nitrate to the media, while this response was absent in the narP mutant. Interestingly, the primary virulence factor, leukotoxin, and the periplasmic component of an iron ABC transporter, FbpA, showed increased production in response to additional nitrate in a NarP dependent manner. In this study, a proteomic approach using ISO-DALT 2D electrophoresis in combination with liquid chromatography-mass spectrometry (LC-MS) was used to identify the proteins regulated by the presence of nitrate in a NarP dependent manner.

\section{Results}

The M. haemolytica A1 proteome

Total proteins extracted from SH1217 grown without $\mathrm{NaNO}_{3}$ supplementation were applied to a $17 \mathrm{~cm}$ IEF strip ( $\mathrm{pH} 5-8)$ and separated by isoelectric focusing. This $\mathrm{pH}$ range was chosen since no proteins were observed between $\mathrm{pH}$ 3-5 and $\mathrm{pH}$ 8-10 in a pilot study using a $7 \mathrm{~cm}$ IEF strip (pH 3-10) (results not shown). The proteins were separated in the second dimension by SDS-PAGE and visualized by Colloidal Coomassie blue staining.

The $M$. haemolytica A1 proteome contained a small number of proteins which were produced in much greater abundance compared to the rest of the proteins (Figure 1). These proteins are estimated to consist up to $15-20 \%$ of the total protein volume. Since a small number of proteins represent a large portion of the total protein concentration, loading the IEF strip with a

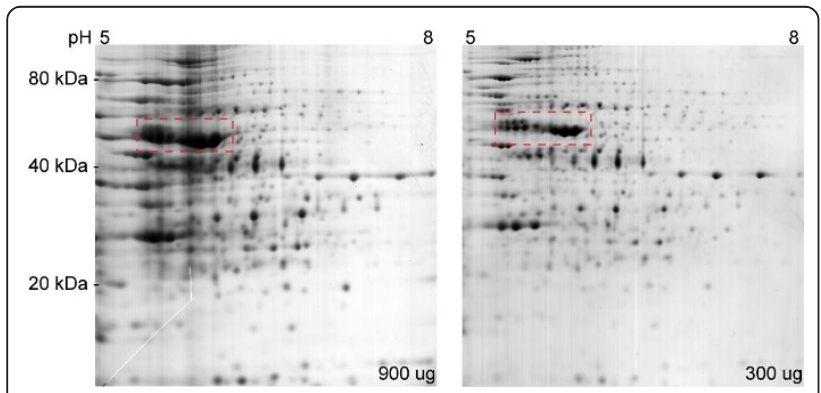

Figure 1 The proteome of $M$. haemolytica $\mathrm{SH} 1217$ shown by ISO-DALT 2D electrophoresis. A total protein load of $900 \mu \mathrm{g}$ or $300 \mu \mathrm{g}$ preparations from SH1217 grown with $\mathrm{NaNO}_{3}$

supplementation were separated by isoelectric focusing on a $17 \mathrm{~cm}$ IEF strip. The proteins were separated in the second dimension by SDS-PAGE and visualized by Colloidal Coomassie blue staining. Dashed boxes note some of the proteins expressed in greater abundance compared to the rest of the proteins. conventional (lower) amount of total proteins causes an under-representation of the rest of the proteins. Thus, in subsequent studies, total protein samples were analyzed under two different protein loads: $300 \mu \mathrm{g}$ of protein load to analyze the abundant proteins and $900 \mu \mathrm{g}$ of protein load to detect the less abundant proteins.

\section{Differential production of proteins in M. haemolytica A1 in response to $\mathrm{NaNO}_{3}$}

Either 900 or $300 \mu \mathrm{g}$ of total proteins extracted from $M$. haemolytica A1 grown with or without $\mathrm{NaNO}_{3}$ supplementation were separated by large format ISO-DALT 2D electrophoresis using a $17 \mathrm{~cm}$ IEF strip ( $\mathrm{pH} \mathrm{5-8).}$ The Colloidal Coomassie stained gels were scanned and analyzed using the BioNumerics Software looking for differentially expressed spots. Prior to this analysis, the volumes of the spots were normalized to the reference spot, shown to be present at a consistent level within the strains and treatments (spot ' $\mathrm{N}$ '; peptidylprolyl isomerase), to adjust for variability in protein loading between each gel.

Twenty-seven spots were identified in SH1217 which were potentially differentially produced in response to $\mathrm{NaNO}_{3}$ supplementation with $900 \mu \mathrm{g}$ of protein load (Figure 2). Seven additional spots were identified to be differentially produced in SH1217 with $300 \mu \mathrm{g}$ of protein load, in response to $\mathrm{NaNO}_{3}$ supplementation (Figure 3). These responses were not observed when the same analyses were carried out on $\Delta \mathrm{NarP7}$ (Figure 4). The analysis was based on three biologically independent samples, each examined on three different gels (i.e.

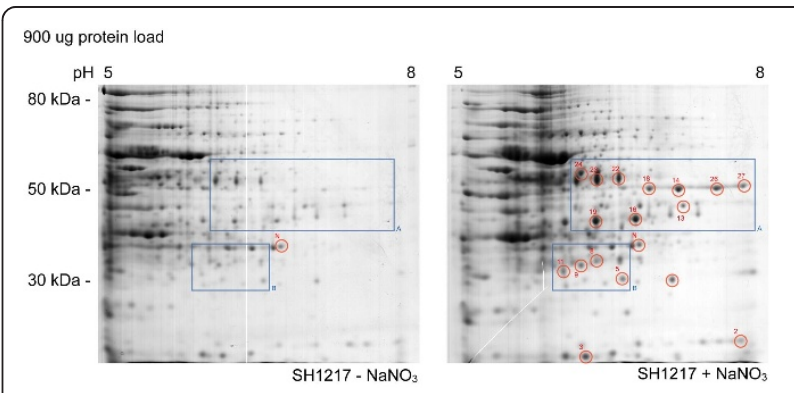

Figure 2 Differential production of proteins in M. haemolytica $\mathrm{SH} 1217$ in response to $\mathrm{NaNO}_{3}$ supplementation in the media, shown by ISO-DALT 2D electrophoresis. A $900 \mu \mathrm{g}$ of total protein preparations from $\mathrm{SH} 1217$ grown with or without $\mathrm{NaNO}_{3}$

supplementation were separated by isoelectric focusing on a $17 \mathrm{~cm}$ IEF strip. The proteins were separated in the second dimension by SDS-PAGE and visualized by Colloidal Coomassie blue staining. Red circles note the spots which showed over 1.5 fold increase in their volume compared to the volume of the same spot in the other gel. These spots were identified by mass spectrometry, and are numbered according to Table 1. The spot used for normalization in statistical analysis is labeled ' $\mathrm{N}$ '. 

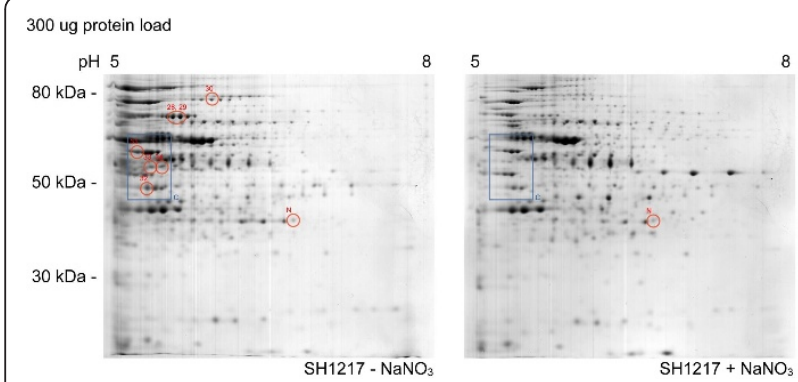

Figure 3 Differential production of proteins in M. haemolytica $\mathrm{SH} 1217$ in response to $\mathrm{NaNO}_{3}$ supplementation in the media, shown by ISO-DALT 2D electrophoresis. A $300 \mu \mathrm{g}$ of total protein preparations from $\mathrm{SH} 1217$ grown with or without $\mathrm{NaNO}_{3}$

supplementation were separated by isoelectric focusing on a $17 \mathrm{~cm}$ IEF strip. The proteins were separated in the second dimension by SDS-PAGE and visualized by Colloidal Coomassie blue staining. Red circles note the spots which showed over 1.5 fold increase in their volume compared to the volume of the same spot in the other gel. These spots were identified by mass spectrometry, and are

numbered according to Table 1 . The spot used for normalization in statistical analysis is labeled ' $\mathrm{N}$ '.

a total of 9 gels), and were shown to be statistically significant at $p<0.05$.

\section{Identification of the differentially produced proteins by mass spectrometry}

Out of the 34 spots identified above, 27 clearly separate ones were identified by liquid chromatography-mass spectrometry (Table 1 ). In some cases, a single protein was represented by multiple spots on the gel. A total of 20 different proteins were identified through mass spectrometry.

The differential production of 17 of the 20 proteins were verified as statistically significant (two-tailed,

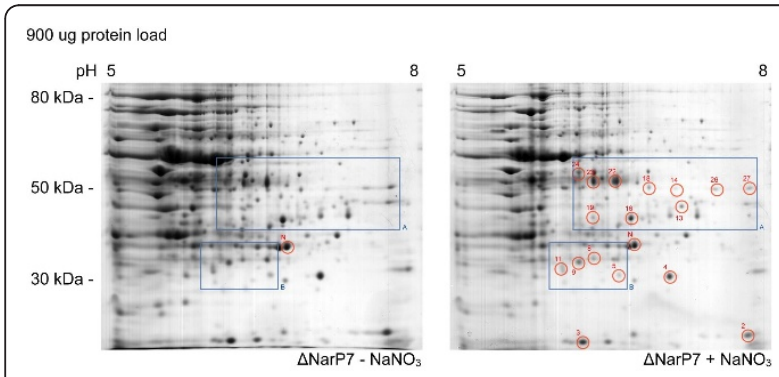

Figure 4 Differential production of proteins in $M$. haemolytica $\triangle \mathrm{NarP7}$ in response to $\mathrm{NaNO}_{3}$ supplementation in the media, shown by ISO-DALT 2D electrophoresis. A $900 \mu \mathrm{g}$ of total protein preparations from $\mathrm{SH} 1217$ grown with or without $\mathrm{NaNO}_{3}$ supplementation were separated by isoelectric focusing on a $17 \mathrm{~cm}$ IEF strip. The proteins were separated in the second dimension by SDS-PAGE and visualized by Colloidal Coomassie blue staining. None of these spots were shown to be differentially produced in $\triangle$ NarP7 under the two $\mathrm{NaNO}_{3}$ conditions. The spot used for normalization in statistical analysis is labeled ' $\mathrm{N}$ '. unpaired t-test $(p<0.05))$. For these proteins, 11 and 6 proteins showed an increased or decreased production, respectively. About half of these proteins were involved in metabolic processes, while other proteins were involved in processes such as transcription and translation. Two iron transport proteins were found on this list; FbpA and YfeA (Figure 5), both of which were strongly over-produced in response to additional $\mathrm{NaNO}_{3}$. None of these proteins were differentially produced in $\Delta$ NarP7 suggesting that the production of these proteins are under direct or indirect control of NarP.

\section{Discussion}

The present study is one of the few reports of the NarP regulon in Pasteurellaceae, along with the study by Ravcheev et al. which was based entirely on in silico methods [10]. Using a proteomic approach, we identified 17 proteins which were differentially produced in response to $\mathrm{NaNO}_{3}$ supplementation in SH1217. This response is $\mathrm{NarP}_{M h}$ dependent since no alteration in the protein levels were observed in the isogenic narP mutant.

The production of two iron transport proteins was found to be regulated by $\operatorname{NarP}_{M h}$. FbpA is the periplasmic component of an iron $\mathrm{ABC}$-transport system, which was produced at over four-fold higher levels in SH1217 in response to $\mathrm{NaNO}_{3}$ supplementation. This agrees with our previous observation [9]. Another iron transporter, YfeA, was expressed at least 2.6 fold higher in response to $\mathrm{NaNO}_{3}$ supplementation. YfeA is a periplasmic iron-binding protein of the YfeABCD iron ATPtransporter system, which transports chelated iron across the inner membrane [11]. This system was first identified in Yersinia pestis and is required for the full virulence of the pathogen [12]. Other HAP organisms such as $H$. influenzae, A. pleuropneumoniae and P. multocida carry yfe $A B C D$ homologues, but all are regulated by iron [13-16]. The NarP mediated nitrate control of YfeA expression has not been reported previously.

Both FbpA and YfeA were represented by multiple, horizontally aligned spots on the 2D gel, having similar masses but different pIs. The separate spots likely represent different isoforms of the proteins generated by post-translational modifications such as phosphorylation or removal of a charged residue, which alter the pI without significantly changing its mass. For instance, FbpA has been shown to be truncated into a slightly smaller $35.5 \mathrm{kDa}$ form after translation [17]. Further, M. haemolytica A1 FbpA binds to ferric iron using a synergistic carbonate anion to stabilize the ligand [18], and therefore the four spots for FbpA may represent the protein bound to its ligands in different combinations (FbpA alone, $\mathrm{FbpA}+\mathrm{Fe}^{3+}, \mathrm{FbpA}+$ carbonate, $\mathrm{FbpA}+\mathrm{Fe}^{3+}+$ carbonate). An observation that transferrin, which shares 
Table 1 Proteins differentially produced in response to $\mathrm{NaNO}_{3}$ supplementation determined by the large-format ISODALT 2D electrophoresis

\begin{tabular}{|c|c|c|c|c|}
\hline Spot \# & $\begin{array}{l}\text { Differential production in } \\
\text { SH } 1217^{\mathrm{a}}\end{array}$ & $\begin{array}{l}\text { Differential production in } \\
\Delta \text { NarP7 }\end{array}$ & Identification (accession number) & $\begin{array}{l}\text { MS Coverage } \\
(\%)\end{array}$ \\
\hline 2 & 2.17 & no response & 50 S ribosomal protein Rpll (197748946) & 52 \\
\hline 3 & 1.82 & no response & Ribosomal protein S6 (53729064) & 53 \\
\hline $4 / 5$ & $1.88 / 1.69$ & no response & $\begin{array}{l}\text { Peptide chain release factor RF4/ribosome recycling factor } \\
\text { (RRF) (197750015) }\end{array}$ & $51 / 26$ \\
\hline 8 & 2.47 & no response & Manganese dependent superoxide dismutase (51292145) & 25 \\
\hline 9 & 1.72 & no response & Xanthine-guanine phosphorybosyltransferase (113460152) & 15 \\
\hline 11 & 1.64 & no response & 3-oxoacyl-[ACP]-reductase (197747648) & 38 \\
\hline 13 & 2.19 & no response & Hypothetical protein (OmpH?) (197749776) & 8 \\
\hline $\begin{array}{l}14 / 18 / \\
26 / 27\end{array}$ & $\begin{array}{l}\text { 4.09/3.7/only in SH+/only in } \\
\mathrm{SH}+\end{array}$ & no response & Iron $\left(\mathrm{Fe}^{3+}\right) \mathrm{ABC}$ Transporter, FbpA (197750010) & $37 / 31 / 29 / 30$ \\
\hline $16 / 19$ & $2.66 / 3.13$ & no response & Iron Transporter, YfeA (110735183) & $38 / 29$ \\
\hline $22 / 23$ & $2.75 / 2.93$ & no response & Glyceraldehyde-3-phosphate dehydrogenase (197749950) & $29 / 29$ \\
\hline 24 & 3.29 & no response & Aspartate transaminase (197749486) & 24 \\
\hline $28 / 29$ & $0.27 / 0.34$ & no response & Phosphophenolpyruvate carboxykinase (197749783) & $30 / 21$ \\
\hline 30 & 0.34 & no response & 2',3'-cyclic-nucleotide 2'-phosphodiesterase (197747925) & 13 \\
\hline 31 & 0.32 & no response & Phosphoglycerate kinase (197750198) & 55 \\
\hline 32 & Only in $\mathrm{SH}$ - & no response & Elongation factor EF1B (197750012) & 36 \\
\hline 33 & Only in SH - & no response & PTS family mannose porter component IIAB (197748528) & 9 \\
\hline 34 & Only in SH - & no response & L-asparaginase II (197747589) & 19 \\
\hline
\end{tabular}

${ }^{\text {a fold-change }}$

The spots were identified by liquid chromatography-mass spectrometry. The spot number corresponds to Figures 2, 3, 4 and 5. Some spots represented the same

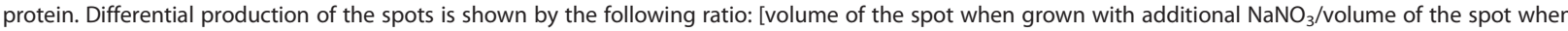
grown without additional $\mathrm{NaNO}_{3}$ ]. Some spots were produced only when $\mathrm{SH}_{12} 17$ was grown with $\mathrm{NaNO}_{3}$ supplementation $\left(\mathrm{Only}\right.$ in $\mathrm{SH}+$ ) or without $\mathrm{NaNO} \mathrm{O}_{3}$ supplementation (Only in $\mathrm{SH}-$ ). The change in the volume of these spots in response to $\mathrm{NaNO}_{3}$ supplementation was not observed in $\Delta \mathrm{NarP7}$ (no response)

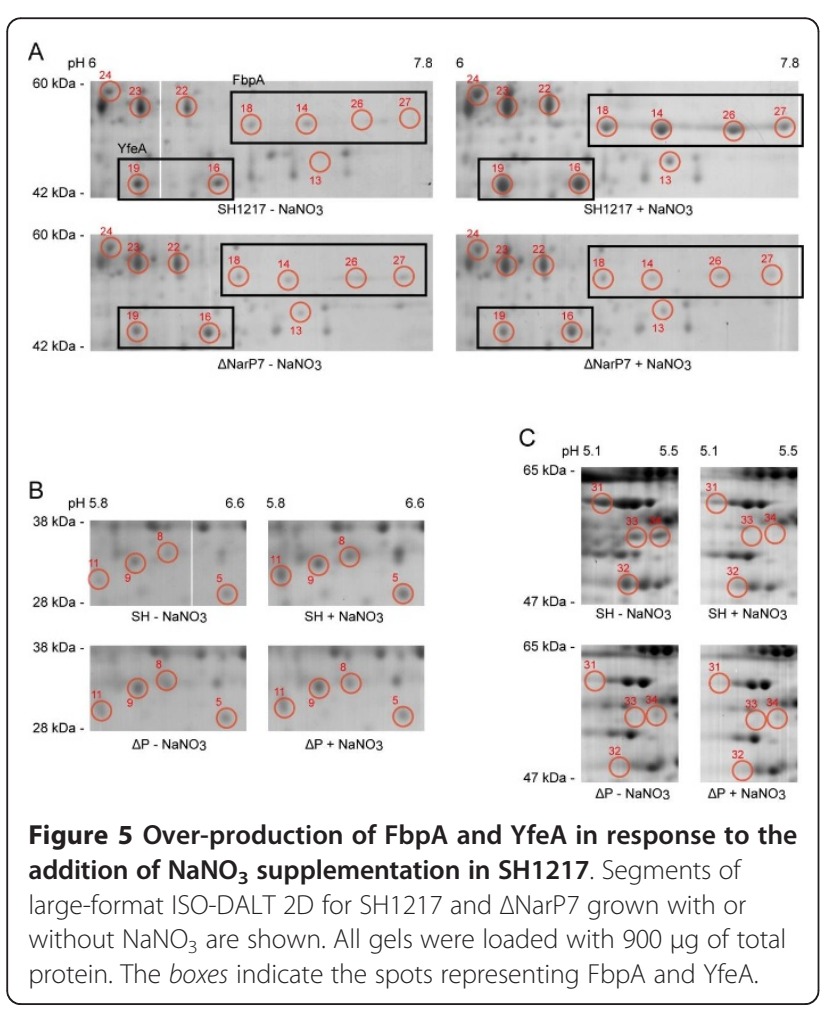

structural/functional similarity to FbpA, remains bound to its ligands during urea-PAGE also support this possibility [19].

Interestingly, expression of napA and its related proteins are heavily dependent on iron, as many of them require the $\mathrm{Fe}_{4}-\mathrm{S}_{4}$ cluster for their function [20]. Studies have shown a down-regulation of the nap operon by the ferric regulator Fur in response to iron deprivation in M. haemolytica, A. pleuropneumoniae, P. multocida, and E. coli $[13-15,21]$, which frees iron for proteins involved in more crucial functions. Thus, we hypothesize that this operon is down-regulated when the microorganism multiplies in the bovine lung where iron is scarce. When it is necessary to carry out nitrate respiration, $\mathrm{NarQP}_{M h}$ system overcomes this negative regulation on NapA by up-regulating several iron transporters such as FbpA and YfeA. The increased iron availability brought by these proteins counteracts the down-regulating effects on the nap promoter from Fur.

Production of superoxide dismutase (SodA) was 2.17 fold higher in response to $\mathrm{NaNO}_{3}$ supplementation. Two forms of superoxide dismutases exist in E. coli: the manganese dependent SodA and the iron dependent SodB [22], M. haemolytica A1 only possess SodA. 
These enzymes protect the cellular components from the reactive oxygen intermediates generated through oxygen metabolism [23]. The importance of SodA in $M$. haemolytica A1 virulence has been implicated as they may protect the bacteria from the oxidative damage caused by neutrophils under leukotoxin attack [24]. The up-regulation of $\operatorname{sod} A$ by the NarP system has been reported in E. coli [25]. Interestingly, Raveheev et al. did not identify $\operatorname{sod} A$ as part of the NarP regulatory network [10]. It is possible that NarP regulates $\operatorname{sod} A$ indirectly.

The up-regulation of napA by the NarQP system in response to environmental nitrate is well established in other organisms [26,27]. In contrast, the over-production of NapA was not detected in our analysis in response to $\mathrm{NaNO}_{3}$. However, a perfect NarP binding sequence was identified in the promoter region of the $M$. haemolytica A1 nap operon (data not shown) which still supports the idea that these genes are regulated by $\mathrm{NarP}_{M h}$.

In many microorganisms, the major role of NarQP is to regulate the expression of nitrate respiration systems, presumably providing an alternate respiration pathway in the oxygen deprived lungs during BPP pathogenesis. This, of course, is mainly accomplished through the production of proteins in the respiratory chain. However, our data suggest that $\mathrm{NarQP}_{M h}$ also regulates the expression of certain proteins such as FbpA and YfeA which does not directly take part in nitrate respiration, but instead aid in the efficient establishment of the system. Further, the system may also play an important role in controlling the production of factors important for virulence, such as SodA (this study) and leukotoxin [9].

This is the first report of the role of $\mathrm{NarP}_{M h}$ regulon in $M$. haemolytica A1, showing that it has expanded its control over the expression of proteins otherwise not known to be controlled by the system in other organisms. This may be a shared trait in Pasteurellaceae, as similar observations were made by Ravcheev et al. [10] for other members of the family using an in silico method based on nucleotide sequence recognition profiles for NarP binding sites. Interestingly, very few genes/proteins were commonly found between our approach and the in silico method. A combination of two reasons explains this difference: 1 ) we were able to detect proteins in the NarP regulon which were missed by the in silico method; and 2) the result simply represent the difference between the NarQP systems in $M$. haemolytica against other members of its family. Nonetheless, our results provide experimental evidence suggesting the expanded role NarQP system in Pasteurellaceae.

\section{Material and methods}

\section{Bacterial strains and growth conditions}

M. haemolytica A1 strain SH1217 was obtained from Dr. Sarah Highlander, Baylor College of Medicine. The $M$. haemolytica A1 narP knock-out mutant strain, $\triangle \mathrm{NarP7}$, was generated from SH1217 [9]. M. haemolytica A1 was cultured in brain heart infusion broth (BHIB) at $37^{\circ} \mathrm{C}$. To examine the response to the addition of nitrate, BHIB was supplemented with $2.5 \mathrm{mM}$ $\mathrm{NaNO}_{3}$. M. haemolytica A1 was grown in a semi-anaerobic condition by growing the liquid cultures in a sealed container without shaking modified from [28].

\section{Extraction of $M$. haemolytica A1 proteins}

An overnight culture of $M$. haemolytica A1 was subcultured in a $1 / 100$ dilution into $750 \mathrm{~mL}$ of pre-warmed BHIB supplemented with $2.5 \mathrm{mM} \mathrm{NaNO}$. The culture was incubated semi-anaerobically at $37^{\circ} \mathrm{C}$ for $5-6 \mathrm{~h}$. The cells were collected by centrifugation $(7,818 \times \mathrm{g})$, and the pellet was washed by resuspending in $30 \mathrm{mM}$ Tris Base ( $\mathrm{pH}$ 10.8). The cells were collected again by centrifugation $(10,270 \times \mathrm{g})$ and lysed in $10 \mathrm{~mL}$ of the $2 \mathrm{D}$ electrophoresis loading buffer (8 M Urea (Fisher) and 4\% (w/v) CHAPS (Sigma-Aldrich) in $30 \mathrm{mM}$ Tris Base $\mathrm{pH}$ 10.8 ) on ice for $5 \mathrm{~min}$. Cell debris were removed by centrifugation at $17590 \times \mathrm{g}$. The extracted protein sample was washed by acetone precipitation (4 volumes of acetone to a volume of the sample), and resuspended in the 2D electrophoresis loading buffer.

The protein concentration of this sample was quantified using the Quick Start ${ }^{\mathrm{TM}}$ Bradford Assay kit (Bio$\mathrm{Rad})$. The $\mathrm{OD}_{595}$ of the samples were determined using a spectrophotometer ( $\left.\mathrm{DU}^{\mathbb{R}} 730\right)$, and their concentrations were calculated using a standard curve generated from serial dilutions of bovine serum albumin, using the onboard program of the spectrophotometer.

Protein samples from two strains, each grown in two different conditions were extracted by this method: SH1217 grown with and without $\mathrm{NaNO}_{3}$ supplementation; and $\triangle \mathrm{NarP7}$ grown with and without $\mathrm{NaNO}_{3}$ supplementation.

\section{Sample preparation and ISO-DALT 2D electrophoresis}

ISO-DALT 2D electrophoresis was performed using the large format, $17 \mathrm{~cm}$ IEF strip (Bio-Rad). The protein samples were diluted appropriately in the rehydration solution (8 M Urea, 4\% (w/v) CHAPS, $10 \mathrm{mM} \mathrm{DTT}$ (Bio-Rad) and 0.2\% (v/v) Bio-Lyte ${ }^{\circledR}$ 3/10 Ampholyte (Bio-Rad). The diluted protein sample was applied to the IEF strip, and the strip was left to rehydrate at RT for 12-16 h. Iso-electric focusing was carried out in the Protean IEF Cell (Bio-Rad), with the following parameters: removal of small ions at $250 \mathrm{~V}$ for $1 \mathrm{~h}$; removal 
of small ions at $500 \mathrm{~V}$ for $2 \mathrm{~h}$; rapid voltage ramping to $10,000 \mathrm{~V}$ for $3 \mathrm{~h}$; iso-electric focusing at $10,000 \mathrm{~V}$ for a total of $60,000 \mathrm{~V}$-hours. Once iso-electric focusing was complete, the IEF strips were equilibrated with the equilibration buffer (6 M Urea, 2\% (w/v) SDS, 20\% (v/v) Glycerol, $130 \mathrm{mM}$ DTT with a trace amount of bromophenol blue (Fisher) in $0.375 \mathrm{M}$ Tris- $\mathrm{HCl},(\mathrm{pH}$ 8.8) for $15 \mathrm{~min}$. The strip was equilibrated for a second time for $15 \mathrm{~min}$ in the equilibration buffer which contained 135 $\mathrm{mM}$ iodoacetamide (Sigma-Aldrich) in place of DTT. Finally, protein on the equilibrated IEF strips were electrophoresed in the second dimension on a large format SDS-PAGE gel. The gels were visualized by Colloidal Coomassie blue staining shown in [29].

\section{Quantitative analysis}

The stained gels were scanned using the GS-800 Calibrated Densitometer (Bio-Rad Laboratories) at the highest resolution. These images were imported to and analyzed by the BioNumerics software (v5.1, Applied Maths). Briefly, protein spots were detected and quantified on each image. The volumes of these spots were then normalized using the reference spot ' $N$ ' (peptidylprolyl isomerase) in each gel to allow the volumes of each spot to be compared between different gels. Queries using Boolean operators were used to detect protein spots which were over-expressed or underexpressed in the protein samples of SH1217 grown with $\mathrm{NaNO}_{3}$ supplementation, as compared to the protein samples of SH1217 grown without the supplementation. A similar analysis was done to determine the differential protein expression in $\triangle \mathrm{NarP7}$ in response to $\mathrm{NaNO}_{3}$ supplementation. These analyses were repeated using three biologically independent samples, and the statistical significance of the differential protein expressions were assessed in a two-tailed, unpaired t-test $(p<0.05)$. A figure showing the gels from 2 biological samples of SH1217 grown without $\mathrm{NaNO}_{3}$ supplementation at a) 900 and b) $300 \mu \mathrm{g}$ loading demonstrating reproducibility of the gels (Additional file 1: Figure S1).

\section{Mass Spectrometry analysis of differentially expressed proteins}

The spots representing the differentially expressed proteins were manually cut out from the Colloidal Coomassie-stained gel. The gel fragments were subjected to ingel trypsin digestion and analyzed by LC-MS at the Mass Spectrometry Facility, University of Guelph. Peptide mass spectra were obtained with a Bruker Reflex IV mass spectrometer. The data was used to search against the NCBI non-redundant protein sequence database using the MS Fit algorithm [30] for proteins matching the peptide mass spectra.

\section{Additional material}

Additional file 1: Figure S1.

\section{Acknowledgements}

This work is funded by a grant from the Natural Science and Engineering Research Council of Canada. We thank Drs. Dyanne Brewer and Armen Charcholyan for their assistance with the Mass Spectrometry MALDI-TOF analysis.

\section{Authors' contributions}

II and RL designed the experimental approach. II carried out most of the laboratory work. Both II and RL analyzed the data and wrote the manuscript.

\section{Competing interests}

The authors declare that they have no competing interests.

Received: 11 July 2011 Accepted: 24 November 2011

Published: 24 November 2011

\section{References}

1. Frank GH: When Pasteurella haemolytica colonizes the nasal passage of cattle. Vet Med 1988, 83:1060-1064.

2. Frank GH, Smith PC: Prevalence of Pasteurella haemolytica in transported calves. Am J Vet Res 1983, 44:981-985.

3. Griffin D: Economic impact associated with respiratory disease in beef cattle. Vet Clin North Am Food Anim Pract 1997, 13:367-377.

4. Mosier DA: Bacterial pneumonia. Vet Clin North Am Food Anim Pract 1997, 13:483-493.

5. Whiteley LO, Maheswaran SK, Weiss DJ, Ames TR, Kannan MS: Pasteurella haemolytica $\mathrm{A} 1$ and bovine respiratory disease: pathogenesis. J Vet Intern Med 1992, 6:11-22

6. Highlander SK: Molecular genetic analysis of virulence in Mannheimia (Pasteurella) haemolytica. Front Biosci 2001, 6:1128-1150.

7. Lo RYC: Genetic analysis of virulence factors of Mannheimia (Pasteurella) haemolytica A1. Vet Microbio/ 2001, 83:23-35.

8. Stock AM, Robinson VL, Goudreau PN: Two-component signal transduction. Annu Rev Biochem 2000, 69:183-215.

9. Inamoto I, Lo RYC: Identification of putative two-component regulatory systems in the bovine pathogen Mannheimia haemolytica A1, and preliminary characterization of the NarQ/P system. FEMS Microbiol Lett 2010, 311:27-35.

10. Ravcheev DA, Gerasimova AV, Mironov AA, Mikhail SM: Comparative genomic analysis of regulation of anaerobic respiration in ten genome from three families of gamma-proteobacteria (Enterobacteriaceae, Pasteurellaceae, Vibrionaceae). BMC Genomics 2007, 8:54-70.

11. Bearden SW, Staggs TM, Perry RD: An ABC transporter system of Yersinia pestis allows utilization of chelated iron by Escherichia coli SAB11. J Bacteriol 1998, 180:1135-1147.

12. Bearden SW, Perry RD: The Yfe system of Yersinia pestis transports iron and manganese and is required for full virulence of plague. $\mathrm{Mol}$ Microbiol 1999, 32:403-414.

13. Deslandes VJ, Nash HE, Harel J, Coulton JW, Jacques M: Transcriptional profiling of Actinobacillus pleuropneumoniae under iron-restricted conditions. BMC Genomics 2007, 8:72-92.

14. Paustian ML, May BJ, Kapur V: Pasteurella multocida gene expression in response to iron limitation. Infect Immun 2001, 69:4109-4115.

15. Roehrig SC, Tran HQ, Spehr V, Gunkel N, Selzer PM, Ullrich HJ: The response of Mannheimia haemolytica to iron limitation: implications for the acquisition o firon in the bovine lung. Vet Microbio/ 2007, 121:316-329.

16. Whitby PW, VanWagoner TM, Seale TW, Morton DJ, Stull TL: Transcriptional profile of Haemophilus influenzae: effects of iron and heme. J Bacteriol 2006, 188:5640-5645.

17. Kirby SD, Lainson FA, Donachie W, Okabe A, Tokuda M, Hatase O, Schryvers $A B$ : The Pasteurella haemolytica $35 \mathrm{kDa}$ iron-regulated protein is an FbpA homologue. Microbiology 1998, 144:3425-3436. 
18. Shouldice SR, Skene RJ, Dougan DR, Snell G, McRee DE, Schryvers AB, Tari LW: Structural basis for iron binding and release by a novel class of periplasmic iron-biniding proteins found in Gram-negative pathogens. J Bacteriol 2004, 186:3903-3910.

19. Williams J, Evans RW, Moreton K: The iron-binding properties of hen ovotransferrin. Biochem J 1978, 173:535-542.

20. Nilavongse A, Brondijk THC, Overton TW, Richardson DJ, Leach ER, Cole JA: The NapF protein of the Escherichia coli periplasmic nitrate reductase system: demonstration of a cytoplasmic location and interaction with the catalytic subunit, NapA. Microbiology 2006, 152:3227-3237.

21. McHugh JP, Rodríguez-Quiñones F, Abdul-Tehrani H, Svistunenko DA, Poole RK, Cooper CE, Andrews SC: Global iron-dependent gene regulation in Escherichia coli. J Biol Chem 2003, 278:29478-29486.

22. Niederhoffer EC, Naranjo CM, Bradley KL, Fee JA: Control of Escherichia coli superoxide dismutase (sodA and sodB) genes by the ferric uptake regulation (fur) locus. J Bacteriol 1990, 172:1930-1938.

23. Hassan MH, Schrum LW: Roles of manganese and iron in the regulation of the biosynthesis of manganese-superoxide dismutase in Escherichia coli. FEMS Microbiol Rev 1994, 14:315-324.

24. Lo RYC: Pasteurella. In Molecular Medical Microbiology. Edited by: Sussman M. Newcastle: Academic Press; 2001:973-986.

25. Constantinidou C, Hobman JL, Griffiths L, Patel MD, Penn CW, Cole JA, Overton TW: A reassessment of the FNR regulon and transcriptomic analysis of the effects of nitrate, nitrite, NarXL, and NarQP as Escherichia coli K12 adapts from aerobic to anaerobic growth. J Biol Chem 2006, 281:4802-4815.

26. Overton TW, Whitehead R, Li Y, Snyder LAS, Saunders NJ, Smith H, Cole JA: Coordinated regulation of the Neisseria gonorrhoeae-truncated denitrification pathway by the nitric oxide-sensitive repressor, NsrR, and nitrite-insensitive NarQ-NarP. J Biol Chem 2006, 281:33115-33126.

27. Wang $H$, Tseng $C$, Gunsalus RP: The napF and narG nitrate reductase operons in Escherichia coli are differentially expressed in response to submicromolar concentrations of nitrate but not nitrite. J Bacteriol 1999, 181:5303-5308.

28. Browning DF, Lee DJ, Wolfe AJ, Cole JA, Busby SJW: The Echerichia coli K$12 \mathrm{NarL}$ and NarP proteins insulate the nrf promoter from the effects of integration host factor. J Bacteriol 2006, 188:7449-7456.

29. Candiano G, Bruschi M, Mustane L, Santucci L, Ghiggeri GM, Carnemolla B, Orecchia P, Zardi L, Righetti PG: Blue silver: a very sensitive colloidal Coomassie G-250 staining for proteome analysis. Electrophoresis 2004, 25:1327-33.

30. Clauser KR, Baker P, Burlingane AL: Role of accurate mass measurement $( \pm$ $10 \mathrm{ppm}$ ) in protein identification strategies employing MS or MS/MS and database searching. Anal Chem 1999, 71:2871-2882.

doi:10.1186/1756-0500-4-510

Cite this article as: Inamoto and Lo: A proteomic analysis of the regulon of the NarP two-component regulatory system response regulator in the bovine pathogen Mannheimia haemolytica A1. BMC Research Notes 2011 4:510

\section{Submit your next manuscript to BioMed Central and take full advantage of:}

- Convenient online submission

- Thorough peer review

- No space constraints or color figure charges

- Immediate publication on acceptance

- Inclusion in PubMed, CAS, Scopus and Google Scholar

- Research which is freely available for redistribution 